\title{
CRISISMUSIC
}

The cultural politics of Rock Against Racism

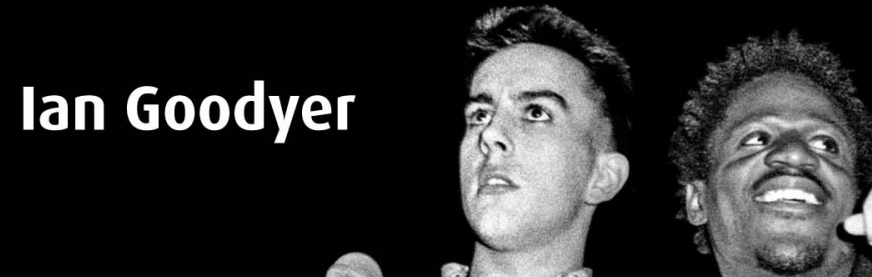




\section{Crisis music}

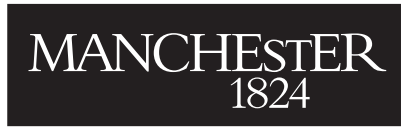

Manchester University Press 
Ian Goodyer - 9781847793003 Downloaded from manchesterhive.com at $04 / 26 / 2023$ 02: $05: 17 \mathrm{PM}$ via free access 


\title{
Crisis music
}

\section{The cultural politics of Rock Against Racism}

\author{
Ian Goodyer
}

Manchester University Press

Manchester and New York

distributed in the United States exclusively by Palgrave Macmillan 
The right of Ian Goodyer to be identified as the author of this work has been asserted by him in accordance with the Copyright, Designs and Patents Act 1988.

\author{
Published by Manchester University Press \\ Oxford Road, Manchester M13 9NR, UK \\ and Room 400, 175 Fifth Avenue, New York, NY 10010, USA \\ www.manchesteruniversitypress.co.uk \\ Distributed in the United States exclusively by \\ Palgrave Macmillan, 175 Fifth Avenue, New York, \\ NY 10010, USA \\ Distributed in Canada exclusively by \\ UBC Press, University of British Columbia, 2029 West Mall, \\ Vancouver, BC, Canada V6T 1 Z2 \\ British Library Cataloguing-in-Publication Data \\ A catalogue record for this book is available from the British Library \\ Library of Congress Cataloging-in-Publication Data applied for
}

ISBN 9780719079245 hardback

First published 2009

$\begin{array}{lllllllllllllllllll}18 & 17 & 16 & 15 & 14 & 13 & 12 & 11 & 10 & 09 & 10 & 9 & 8 & 7 & 6 & 5 & 4 & 3 & 2\end{array}$

The publisher has no responsibility for the persistence or accuracy of URLs for external or any third-party internet websites referred to in this book, and does not guarantee that any content on such websites is, or will remain, accurate or appropriate.

Typeset by SNP Best-set Typesetter Ltd, Hong Kong

Printed in Great Britain

by CPI Antony Rowe Ltd, Chippenham, Wiltshire 